\title{
Impact Assessment of Skill Development Trainings Rendered by Punjab Rural Support Programme for Empowering Rural Women
}

\author{
Ayesha Riaz \\ Institute of Rural Home Economics, University of Agriculture, Faisalabad, Pakistan \\ Aisha Siddique \\ Institute of Rural Home Economics, University of Agriculture, Faisalabad, Pakistan \\ Farah Riaz \\ Institute of Rural Home Economics, University of Agriculture, Faisalabad, Pakistan \\ Nazia Malik \\ Assistant Professor, Government Collage University Faisalabad, Pakistan
}

Doi:10.5901/ajis.2014.v3n4p27

Abstract

The present study was designed to assess the usefulness, strength, weaknesses and participants recommendations for the Skill Development Trainings (SDT) rendered by Punjab Rural Support Programme (PRSP) for empowering rural women. The population for the study consisted of rural women only who were the members of Community Organizations (COs) of PRSP in district Faisalabad. A total sample size of 410 respondents was selected through a multistage simple random sampling technique. The data was analyzed using SPSS. The study revealed that the trainings provided by PRSP was considered useful by rural women and empowered them in certain areas as decision making, self-reliance and confidence building. The study further identified strengths, weaknesses and recommendations for the improvement of SDT. Though the SDT contributed a lot in empowering women still their impact on income generation is at satisfactory level. Need oriented trainings, opportunities of employment and provision of small enterprise is needed for women empowerment.

Keywords: Skill Development Trainings, Women Empowerment, Non-Government Organisation, Rural Women

\section{Introduction}

No one can reject the fundamental role women play today in the society. In spite of the fact the culture of male chauvinism is customary in the world. This practice is quite severe in Pakistani society where all issues relating to outside the home are usually looked after by male members. The women have to remain confined to the household responsibilities and other domestic tasks. In rural areas, in spite of the busy routine of women at home they have to do a lot of work regarding agriculture and livestock. Although the female input in such activities is highly noteworthy, it has never been recognized (Chaudhry, 2005). A net of many aspects like economic, cultural and social contribute towards granting women a below par status which leads to further deprivation and discrimination. And these are the factors that hinder the struggle for women empowerment and development (Singh \& Singh, 2005).

Women empowerment is an active, productive and multidimensional procedure through which women can enable themselves to capture their true identity in every sphere of life (NAAS, 2001). According to Rooij (2005) women's empowerment is the procedure in which, women individually and collectively act as vigorous, energetic, well informed, and goal-oriented persons who are eager and prepared to take steps to overcome gender discrimination. Women's empowerment contemplates the achievements of control of one's own self, liberation from violence; equal right to use and control resources, voice and authority in the decision-making processes of society, equal opportunity for leadership, and eradication of gender stereotypical customs and roles.

Skill development trainings are very necessary especially for rural women in order to engage them in constructive and income generating activities. According to Wentling (1993) there is a constant need to provide people with new 
knowledge or new skills that are necessary to implement a change and training is a potential solution. Training is a key mechanism for developing the skills of individuals, thus enhancing human resources. When peoples' skills are improved, they produce more, become happier, and contribute more to the wellbeing of their families, communities and countries

The status of females in the society has to be improved and the path to achieving this objective is via turning them into earning members. The status of working women relating to income generating activities like cottage industry, family handicraft business, agricultural activities and other small businesses is most likely to be better than housewives who are not given the opportunity to contribute anything to family income. Obviously both men and women in the household need to work to make ends meet. Participation of women in income generating activities would also help them alleviate their poverty, attain better level of education, and enjoy improved health conditions. This would have a huge positive effect on security of the household and nourishment of children than depending on man's income alone (Ahmad et al., 2003). Women should also be allowed by their guardians to learn functional skills to improve their economic status (Danjuma et,al., 2011).

ILO (2008) reported that education and skills training enhance the capability of women and men to apply new techniques, thus increasing their potential for being employed as well as the productivity and competitiveness of enterprises. A very vital and crucial role can be played by developing skill enhancing systems which should connect education to technical training and technical training to entry into the labour market which in turn would help them secure good and reasonable employment which can be a source of learning for the rest of their lives.

Training of rural manpower is considered one of the most important strategies for ensuring sustainable development. However mostly rural women are underprivileged in comparison to men in their access and abilities to partake in education and training. The result has been the delimitation of females to have proper access to training and a host of different occupations which in return stopped them from having reasonable and decent incomes and social advancement (UNESCO, 2006).

In the existing scenario, where the women are becoming the catalyzing agents for stabilizing the economy in both urban and rural areas there is a dire need to train women folk. Besides government institutions Non-Government Organisations (NGOs) also continue to play a leading role in ensuring that rural women receive training, information and improved technologies. At present NGOs are playing a very important role in providing services to rural women regarding education, poverty alleviation, family planning, health related issues, population, and conservation of environment and development of non-formal education. PRSP is a well established NGO with the mission of harnessing peoples' potential by helping themselves. It has been providing services for rural women in the Punjab since long, having a mandate of rural women empowerment by introducing income generating and skill based activities. PRSP conducts different skill development trainings for rural women with the collaboration of members of COs. The main objective of the skill development training is to train rural people to bring about improvement in their income which ultimately leads towards better living standards. These skill development trainings are arranged by PRSP on multi-dimensional spheres of life, keeping in view the requirements of local people. The trained people are also preferred by the PRSP for provision of credit to support them for initiation of their own business. The present study was designed to assess the skill development trainings rendered by PRSP for empowering women with regard to usefulness, effectiveness and identified strengths, weaknesses and recommendation for improvement.

The study proceeds with the following objectives:

i. To determine the usefulness of various skill development trainings.

ii. To identify the strengths and weaknesses of skill development trainings.

iii. To assess the areas improved as a result of skill development trainings.

iv. To get recommendations regarding the improvement of SDT from respondents

\section{Materials And Methods}

The present study was conducted in district Faisalabad. The population for the study consisted of women who were the members of community organizations of PRSP. A multistage simple random sampling technique was used for the study. Out of eight towns of district Faisalabad, four towns which cover rural areas (Samundri, Iqbal Town, Jaranwala, and Chak Jhumra) were selected with the reason that the focus of study was on rural women. Four field units of PRSP are working in these four towns i.e. Salarwala in Chak Jhumra, Satiana in Jaranwala, Khidarwala in Samundri, and Dijkot in Iqbal Town. These field units have 214, 203, 170 and 238 female Community Organizations (COs) respectively. Sample of $10 \%$ COs was selected from each field unit randomly. Thus the total selected COs was 82 . Five members from each COs were selected at random making the total sample size of 410 respondents. A reliable and validated data collection 
instrument was employed keeping in mind the research objectives. The data was analyzed using SPSS.

\section{Results And Discussion}

Table 1: Rank order, means and standard deviation of the usefulness of skill development trainings

Scale: Not useful 12345 Very useful, $X=$ No response

\begin{tabular}{|l|c|c|c|c|}
\hline \multicolumn{1}{|c|}{ Skill development trainings } & Rank order & Weight score & Mean & Std. Deviation \\
\hline Tie and dye & 1 & 186 & 3.72 & 0.95 \\
\hline Fabric painting & 2 & 85 & 3.54 & 0.35 \\
\hline Glass painting & 3 & 53 & 3.11 & 0.19 \\
\hline Beautician course & 4 & 51 & 3.64 & 0.36 \\
\hline Stove Making & 5 & 51 & 3.40 & 0.21 \\
\hline Village based stitching training (VBST) & 6 & 40 & 2.66 & 0.87 \\
\hline Candle making & 7 & 36 & 3.27 & 0.84 \\
\hline Detergent and shampoo making & 8 & 35 & 2.91 & 0.17 \\
\hline Traditional birth training (TBT) & 9 & 28 & 3.11 & 0.41 \\
\hline Livestock & 10 & 25 & 2.77 & 1.27 \\
\hline Bee keeping training & 11 & 21 & 3.00 & 0.92 \\
\hline Food preservation & 12 & 20 & 2.85 & 1.02 \\
\hline
\end{tabular}

The respondents were asked about the usefulness of skill development trainings and their ranking is shown in Table 1. The training of tie and dye was ranked $1^{\text {st }}$ with mean value 3.72 showing its tendency toward very useful. Beautician course with mean value 3.64 also had the tendency towards very useful. Other trainings like fabric painting (mean=3.54), glass painting (mean=3.11), stove making (mean=3.40), candle making (mean=3.27) and traditional birth training (mean=3.11) were considered moderately useful. Village based stitching training (VBST) mean value 2.66, detergent and shampoo making (mean=2.91), livestock (mean=2.77), and food preservation (mean=2.85) were also considered moderately useful. According to (Naveed et.al.) short training programs related to crop production, livestock care and management, human health and sanitation and handicrafts are necessary for the capacity building especially for desert women.

Table 2: Rank orders, means and standard deviation of various aspects based on respondents' perception about the improvement in the following areas occurred as a result of skill development trainings

Scale: 1= Poor, 2=Fair, 3= Satisfactory, 4= Good, 5= Excellent, $X=$ No response

\begin{tabular}{|l|c|c|c|c|}
\hline \multicolumn{1}{|c|}{ Areas } & Rank order & Weight score & Mean & Std. Deviation \\
\hline Reduction in expenditure & 1 & 653 & 3.75 & 0.90 \\
\hline Self-reliance & 2 & 628 & 3.54 & 1.44 \\
\hline Confidence building & 3 & 585 & 3.40 & 0.86 \\
\hline Decision making & 4 & 547 & 3.19 & 0.98 \\
\hline Income generation & 5 & 534 & 3.51 & 1.00 \\
\hline Working efficiency & 6 & 509 & 3.39 & 1.02 \\
\hline Learning ability & 7 & 454 & 3.26 & 0.92 \\
\hline
\end{tabular}

The ranking of the areas and various aspects improved as a result of skill development trainings is presented in Table 2 which shows that reduction in expenditure, self-reliance and income generation were ranked $1^{\text {st }}$ and $2^{\text {nd }}$ with mean values $3.75,3.54$ respectively and fell in between satisfactory and good categories but tended more toward good category. Protz (2001) narrated in this connection that many women learned new skills as a means to save money rather than to make money. However, income generation also fell in between satisfactory and good categories but tended more toward good category and was ranked $5^{\text {th }}$ with mean value 3.51. Shaista (1989) was of the view that a large number of rural women were willing to take part in income generating activities due to the reason that income levels of their husbands were very low and they wanted increase in income to improve their family living through these activities. The ranking of income generation at no. $5^{\text {th }}$ may be due to the fact described by Protz (2001) that when women participate in income-generating activities and have to go outside of their homes to do that, it represents a higher exposure to risk for them especially when their social roles and responsibilities, their mobility in the society and the range of their social interactions are 
narrowly and very rigidly defined and practiced. Areas like working efficiency and learning ability also fell in between satisfactory and good categories but tended toward satisfactory category and were ranked $6^{\text {th }}$ and $7^{\text {th }}$ with mean values 3.39 and 3.26 , respectively. Training involves the facilitation of learning by people who can benefit by attaining new knowledge, skills or attitude (Wentling, 1993). Asif (2003) narrated in this connection that training must focus on the real needs of people. Training which fails to meet learning needs is waste of time, effort, and resources. Rural women's training is necessary especially in case when any formal education is absent. Training programs can enhance their efficiency and competency. Trainings programs like tailoring, beautician, farming, poultry, card making and Traditional Birth Attendant could be fruitful in income generation perspective. According to Anuradha and Reddy (2013) vocational education and training can play a vital role for many of the rural women by improving household productivity, incomeearning opportunities, employability and also for enhancing food security and promoting sustainable rural development.

Table 3: Rank order, means and standard deviation of strengths of skill development trainings conducted by PRSP

Scale: 1=S. disagree 2=Disagree 3=Somewhat agree 4=Agree 5=S. agree $X=$ No response

\begin{tabular}{|l|c|c|c|c|}
\hline \multicolumn{1}{|c|}{ Strengths } & $\begin{array}{c}\text { Rank } \\
\text { order }\end{array}$ & Weight score & Mean & Std. Deviation \\
\hline Simple and familiar words are used by the trainers & 1 & 732 & 3.87 & 0.51 \\
\hline Trainings are conducted at appropriate place & 2 & 573 & 3.79 & 0.44 \\
\hline Participants are informed about the trainings well in time & 3 & 558 & 3.57 & 0.55 \\
\hline Skill development trainings are need oriented & 4 & 525 & 3.77 & 0.74 \\
\hline Trainings are arranged at proper time & 5 & 485 & 3.34 & 0.62 \\
\hline Training material is well organized and presented in logical sequence & 6 & 454 & 3.78 & 0.56 \\
\hline Trainees are actively involved in implementing trainings & 7 & 429 & 3.02 & 0.52 \\
\hline Trainees are actively involved in planning training programmes & 8 & 407 & 2.67 & 0.79 \\
\hline Needed facilities are made available to trainers & 9 & 359 & 3.09 & 0.62 \\
\hline All the needed materials and equipment are timely secured & 10 & 279 & 3.17 & 0.46 \\
\hline Sufficient audio-visual equipment are used in the trainings & 11 & 170 & 2.00 & 1.49 \\
\hline
\end{tabular}

The ranking of strengths of skill development trainings conducted by PRSP is presented in Table 3 . The data show that the aspects like "simple and familiar words are used by the trainers" (mean=3.87), "trainings are conducted at appropriate place" (mean=3.79), "participants are informed about the trainings well in time" (mean=3.57), "skill development trainings are need oriented" (mean=3.77) and "training material is well organized and presented in logical sequence" (mean=3.78). According to Wentling (1993) a good training must involve the trainees into learning not just listening through motivation. The contents must relate to the needs of trainees and there must be inherent logical organization of training contents. The sequence of content is very important because it may have a considerable effect on the efficiency of learning. "Trainees are actively involved in implementing trainings", "needed facilities are made available to trainers" and "all the needed materials and equipment are timely secured" also fell in between the somewhat agree and agree categories but were tended toward somewhat agree category with mean values 3.02, 3.09 and 3.17, respectively. Support material and equipment are necessary for effective training. It can vary from simple trainer constructed aids to complex, commercially produced materials. Trainers should be aware of both and should use what best meet their needs (Wentling, 1993). "Trainees are actively involved in planning training programmes" fell in between disagree and somewhat agree categories but was tended toward somewhat agree category with mean value 2.67. The aspect like "sufficient audio-visual equipment are used in the trainings" with mean value 2.00 fell under disagree category. The training is a term which covers a wide range of activities. The systematic approach to training is a result oriented process designed to ensure that training is both relevant and effective. A good training must be need oriented and conducted in a simple manner so that everyone can earn benefit from it. In this connection Rangnekar, (2003) narrated that there is a need to redesign trainings sessions according to rural women's requirements. Trainings should be practical, need oriented and short-term. Audiovisual material must be used and trainings must be conducted at the right time of the day and close to the women's homes. 
Table 4: Rank order, means and standard deviation of weaknesses of skill development trainings conducted by PRSP

Scale: $1=$ S. disagree $2=$ Disagree $3=$ Somewhat agree $4=$ Agree $5=S$. agree $X=$ No response

\begin{tabular}{|l|c|c|c|c|}
\hline \multicolumn{1}{|c|}{ Weaknesses } & $\begin{array}{c}\text { Rank } \\
\text { order }\end{array}$ & Weight score & Mean & Std. Deviation \\
\hline Too much contents are presented in one session & 1 & 493 & 2.72 & 0.42 \\
\hline Training materials are arranged by the participants & 2 & 466 & 2.69 & 0.44 \\
\hline Only males are involved as trainers & 3 & 453 & 2.71 & 0.42 \\
\hline Contents of trainings are difficult to follow & 4 & 385 & 2.11 & 0.53 \\
\hline Male are given preference for trainings & 5 & 346 & 2.09 & 0.42 \\
\hline Trainers are not competent to conduct the trainings & 6 & 333 & 1.99 & 0.20 \\
\hline Only resourceful people are encouraged to attend the trainings & 7 & 306 & 1.85 & 0.20 \\
\hline Only literates can get benefit from trainings & 8 & 282 & 1.52 & 0.34 \\
\hline
\end{tabular}

A training program may have some weaknesses. Identification and correction of weaknesses can make training more effective and useful for trainees. Therefore respondents were asked to identify weaknesses in the skill development trainings. The data show that statements like "too much contents are presented in one session", "training materials are arranged by the participants" and "only males are involved as trainers" ranked $1^{\text {st }}, 2^{\text {nd }}$ and $3^{\text {rd }}$ with mean values $2.72,2.69$ and 2.71 and fell in between the somewhat agree and disagree categories but was tended toward somewhat agree category. The aspects like "contents of trainings are difficult to follow" and "male are given preference for trainings" with mean values 2.11 and 2.09 were ranked $4^{\text {th }}$ and $5^{\text {th }}$ fell in between somewhat agree and disagree categories but were tended toward disagree category. The aspect like "trainers are not competent to conduct the trainings", "only resourceful people are encourage to attend the trainings" and "only literates can be benefit from trainings" with mean values 1.99 , 1.85 and 1.52 were ranked $6^{\text {th }}, 7^{\text {th }}$ and $8^{\text {th }}$ respectively and fell in between the strongly disagree and disagree categories but were tended toward disagree category.

Table 5: Recommendations from respondents regarding the improvement in skill development trainings towards women empowerment

\begin{tabular}{|l|l|c|}
\hline \multicolumn{1}{|c|}{ Suggestions of respondents } & No. & $\%$ \\
\hline Opportunities for employment & 396 & 96.60 \\
\hline Provision of small enterprise & 341 & 83.20 \\
\hline AV aids should be used during trainings & 165 & 40.24 \\
\hline Establishment of equipped stitching and embroidery unit & 160 & 39.02 \\
\hline More need oriented technical and skill development trainings & 156 & 38.05 \\
\hline Helping material should be provided to trainees & 149 & 36.34 \\
\hline Linkage with factories and marketing provision & 135 & 32.93 \\
\hline
\end{tabular}

The respondents were asked about their suggestions for the improvement of services of PRSP for women empowerment, which are presented in Table 6. An overwhelming majority (96.60\%) of the respondents was of the view that there should be opportunities of employment for women. Similarly $83.20 \%$ respondents suggested provision of small enterprise. About $39 \%$ respondents suggested establishment of equipped stitching and embroidery units. Linkage with factories and marketing provision was another suggestion given by $32.93 \%$ respondents. Anuradha and Reddy (2013) also suggested that the policy planning for the empowerment of rural women through vocational trainings must include a genderresponsive strategy for education, training and entrepreneurship. Improved curricula that complement vocational and technical training with numeracy and literacy training for the rural women must be developed. Trainings related to gender issues and life skills such as health, nutrition, confidence building and leadership skills must also be given to rural women.

\section{Conclusions and Recommendations}

It can be concluded from the results that the SDT provided by PRSP was considered useful by rural women and empowered them in certain areas as decision making, self-reliance and confidence building. The study further identified strengths, weaknesses and recommendations for the improvement of SDT. The training of tie and dye was the only most attended and useful training. The rest of the trainings were perceived to be moderately useful. The SDT were need 
oriented and training material was well organized and presented in logical sequence. However, trainees were not actively involved in implementing trainings. The use of sufficient audio-visual equipment in the trainings was an area which required much attention. The respondents were to some extent agreed about the weakness that too much contents were presented in one session, training materials were arranged by the participants and only males were involved as trainers. The reduction in expenditure is the most important area of improvement covered through the skill development trainings followed by self-reliance and income generation. Therefore, PRSP should engage trainees in planning and implementing training sessions. In order to make the training sessions more effective and purposeful, the availability of reference materials and use of audio/visual aids must be increased. Provision of employment and small enterprises is needed in order to make women empowered.

\section{References}

Ahmad, B., N. Tabassum and P.A. Gill. 2003. Diagnosing Priorities for Rural Women's Welfare Through Participatory Approaches in the Punjab, Pakistan. Available at: http://www.iied.org/NR/agbioliv/pla_notes/documents/plan_04614.pdf

Anuradha, R.V and G.L.Reddy. 2013. Empowerment of Rural Women Through Vocational Education and Training. Conflux Journal of Education ISSN 2320-9305 Volume 1, Issue 2, http://www.naspublishers.com

Asif, N. 2000. Utilization of Vocational Training Sialkot Region. An Impact Study of NRSP-Sialkot. NRSP Monitoring Assessment and Planning Section.

Chaudhry, A. G. 2005. Social Mobilization and Economic Empowerment of Women: A case Study in Selected Areas of AJK. Pak. J. of Soc. Sci. 3(2): 309-313.

Danjuma, K.Safiya, Malami, Hussaini Usman; Gatawa, Nasiru. 2011. Skill Acquisition, Capacity Building and Women Economic Empowerment: A Case Study of Women Education Center, Birnin Kebbi. Gender \& Behaviour, Vol. 9, No.2

ILO. 2008. From Veil to Camera: Empowering Women Through Skill Training http://www.ilo.org/global/About_the_ILO /Media_and_public_information/Feature_stories/lang--en/WCMS_100390/index.htm

NAAS. 2001. Empowerment of women and diversification in Agriculture. National Academy of Agriculture Sciences, India. www.nasindia.org/Policey\%2520 Papers/ pp11.pdf pk

Naveed I, T. Ali, M. Ahmad, A. A Maan and Q. Haq. 2009. Training Needs of Rural Women in Agriculture: A Case Study of District Bahawalapur, Pakistan. Pak. J. Agri. Sci., Vol. 46(3),

Protz, M. 2001. Gender Impact Analysis of the Mansehra Village Support Project and the Neelum and Jhelum Valleys Community Development Project, Rome . Available at: www.ifad.org/gender/learning/sector/e

Rangnekar, S.D. 1993. Studies on the knowledge of rural women regarding local feed resources and feeding systems developed for livestock. International Conference on Increasing Livestock Production through Utilization of Local Resources. CECAT, Beijing, 18-22 October, 1993

Rooij, S. 2005. Institutional Capacity Building for Rural Women's Empowerment. EJPAU 8(3), \# 30. Available at: http://www.ejpau.media. pl/volume8/issue3/art-30.html

Shaista, R. 1989. A Sociological Study of Immigrant Families in Kachi Abadies of City Faisalabad. Unpublished M.Sc Thesis, Department of Rural Sociology, University of Agriculture, Faisalabad, Pakistan.

Singh, D. P. and M. Singh. 2005. Women and Empowerment: Experiences from Some Asian Countries. Unistar Books.

UNESCO. 2006. Technology-based Vocational Training for Marginalized Girls (TVT-G). Available at: http:/lunesdoc.unesco.org limages/0015/001511/151183e.pdf

Wentling, T. 1993. Planning for Effective Training: A Guide to Curriculum Development. FAO, Italy. 